\title{
MILNESIUM LAGNIAPPE, A NEW SPECIES OF WATER BEAR (TARDIGRADA, EUTARDIGRADA, APOCHELA, MILNESIIDAE) FROM THE SOUTHERN UNITED STATES
}

\author{
Harry A. Meyer1,2, Juliana G. Hinton ${ }^{1}$, and Maria C. Dupré ${ }^{1}$
}

\begin{abstract}
Over 200 species of freshwater and terrestrial water bears (phylum Tardigrada) are known to occur in North America. Of these, 20 species have been recorded in Louisiana. Foliose and fruticose lichen and moss samples collected in 2011 in the city of Lake Charles and in Sam Houston Jones State Park, Calcasieu Parish, Louisiana, USA, were stored in paper envelopes and later soaked in tap water overnight. Tardigrade specimens and eggs were extracted and mounted in polyvinyl lactophenol. The samples contained a new species of tardigrade. Milnesium lagniappe sp. $\mathbf{n}$. has claw formula [2-3]-[3-2] and 9 sculptured bands in the dorsal and lateral cuticle. The new species most closely resembles Milnesium reticulatum, a species known only from the Seychelles Islands, in its cuticular pattern. However, M. lagniappe sp. n. is almost twice as large as $M$. reticulatum, lacks gibbosities, has proportionally wider buccal tube and longer claws, and has a more posterior point of stylet insertion. Reexamination of tardigrades from central Florida, USA, previously reported as $M$. tardigradum shows that they are in fact M. lagniappe sp. n.
\end{abstract}

Resumen.-Se sabe que hay más de 200 especies de tardígrados terrestres y acuáticos (phylum Tardigrada) en Norteamérica, de las cuales se registraron veinte en Louisiana. Las muestras de liquen folioso y fructiculoso y de musgo que se recogieron en la ciudad de Lake Charles y en Sam Houston Jones State Park, Calcasieu Parish, Louisiana, Estados Unidos, en el año 2011, se colocaron en sobres de papel y luego se enjuagaron con agua corriente durante la noche; posteriormente se extrajeron especímenes de tardígrados y huevos, los cuales se montaron con polivinil lactofenol, y se observó que las muestras contenían una nueva especie de tardígrados. Milnesium lagniappe sp. n. tiene fórmula de garras [2-3]-[3-2] y nueve bandas esculpidas en la cutícula dorsal y lateral. La nueva especie se parece a Milnesium reticulatum, una especie que sólo se ha registrado en las Islas Seychelles, en su patrón cuticular, pero tiene el doble de tamaño, carece de jorobas, tiene un tubo bucal proporcionalmente más ancho, garras más largas y el punto de inserción del estilete se encuentra más atrás. La reevaluación de los tardígrados del centro de Florida, Estados Unidos, que se indicó anteriormente como M. tardigradum, muestra que, de hecho, son M. lagniappe sp. n.

Tardigrades (phylum Tardigrada), commonly known as water bears, are microscopic animals found in marine, freshwater, and terrestrial habitats. Terrestrial species occur in mosses, lichens, liverworts, and leaf litter and are renowned for their ability to enter a cryptobiotic state (anhydrobiosis) in response to desiccation. Terrestrial tardigrades include both herbivores and carnivorous species that feed on nematodes, rotifers, and other tardigrades. Over 200 species of freshwater and terrestrial tardigrades (phylum Tardigrada) are known to occur in North America (Meyer and Hinton 2007). Of these, 20 have been found in Louisiana, USA (Meyer 2001, Hinton and Meyer 2007, Hinton et al. 2010, Meyer and Domingue 2011), and 21 in Florida, USA (Christenberry and Mason 1979, Grigarick et al. 1983, Meyer 2006, 2008, 2009, Hinton et al. 2010).
Herein we describe a new species belonging to the genus Milnesium Doyère, 1840, collected from lichens and mosses in Calcasieu Parish, Louisiana, and Lee County, Florida.

\section{Methods}

Moss, foliose and fruticose lichen, and leaf litter samples were collected in March and September 2011 and March 2012 in urban areas of the city of Lake Charles and along second-growth woodland trails in Sam Houston Jones State Park (SHJSP). Both sites are located in Calcasieu Parish, Louisiana. Samples were stored in sealed paper envelopes. In the laboratory, samples were soaked overnight to rehydrate tardigrades. After soaking, the material was sieved, and the residue retained by $42-\mu \mathrm{m}$ mesh was examined with a dissecting microscope (Nikon SMZ-U Zoom 1:10).

\footnotetext{
${ }^{1}$ Department of Biology and Health Sciences, McNeese State University, Lake Charles, LA 70609

2E-mail: hmeyer@mcneese.edu
} 
Tardigrade specimens were mounted on slides in polyvinyl lactophenol and examined using phase microscopy (Nikon Eclipse 50i). Specimens from Lee County, Florida, identified in Meyer (2008) as Milnesium tardigradum Doyère, 1840, were reexamined.

Specimens were measured using imaging software (NIS-Elements D 2.30, SPI). The $p t$ index, expressed as a percentage, is the ratio of the length of a given structure to that of the buccal tube (Pilato 1981). Morphometric analysis and terminology follow the recommendations of Tumanov (2006) for claws and Michalczyk et al. (2012a, 2012b) for the buccal tube and associated structures. Morphometric data were handled using the Apochela ver. 1.0 template available from the Tardigrada Register (www.tardigrada.net/register). In type descriptions, $p t$ indices are put in bracketed italics. Body length was measured from the mouth to the posterior end, excluding hind legs. Buccal tube length and the insertion point of the stylet supports were measured from the anterior margins of the stylet sheaths; the posterior end of the buccal tube was taken as the point where the wall had thinned to the extent that outer and inner buccal tube diameter were no longer distinguishable. Buccal tube width was measured at the external diameter at 3 points: anterior, standard (at the point of stylet support insertion), and posterior (at the point where the buccal tube wall starts to thin and curve inwards). Lengths of primary and secondary branches of claws were measured as illustrated in Tumanov (2006).

Comparisons between the new species and other species are based on literature descriptions and 2 paratypes of Milnesium reticulatum Pilato, Binda and Lisi, 2002.

\section{Taxonomic Account}

\section{Milnesium lagniappe sp. $\mathrm{n}$.}

(Figs. 1-3, Table 1)

DiagnOSIS.-A Milnesium of the Milnesium granulatum group (sensu Michalczyk et al. 2012a, 2012b) with claw formula [2-3]-[3-2], 4 peribuccal lamellae visible with light microscopy, cylindrical buccal tube, cuticle without gibbosities, with smooth cuticle except for 9 dorsal and lateral sculptured bands bearing a reticulated pattern of polygons, and with stout claws with well-developed accessory points.
Material EXAMINED AND DEPOSIT OF TYPES.- River Road, Lake Charles, Louisiana $\left(30^{\circ} 14^{\prime} 49^{\prime \prime} \mathrm{N}, 93^{\circ} 13^{\prime} 33^{\prime \prime} \mathrm{S}, 1 \mathrm{~m}\right.$ elevation; fruticose and foliose lichen on trees): 3 female paratypes (slides SMLA 16002, 16005). Blue Trail, SHJSP, Louisiana $\left(30^{\circ} 17^{\prime} 44^{\prime \prime} \mathrm{N}, 93^{\circ} 16^{\prime}\right.$ $18^{\prime \prime} \mathrm{S}, 4 \mathrm{~m}$ elevation; foliose lichen on Liquidambar styraciflua L.): 9 female, 1 male paratypes (SMLA 12042, 12058-12060). Yellow Trail, SHJSP: holotype, 1 female paratype (SMLA 12050; deciduous leaf litter at base of L. styraciflua); 1 female, 1 male paratype (SMLA 12051, 12055; moss on L. styraciflua). River Walk Trail, SHJSP $\left(93^{\circ} 15^{\prime} 44^{\prime \prime} \mathrm{N}, 30^{\circ} 17^{\prime}\right.$ $36^{\prime \prime} \mathrm{S}, 1 \mathrm{~m}$ elevation; moss on Pinus sp.): 1 male paratypes (SMLA 12026). Seventy-two additional specimens collected in Lake Charles and SHJSP.

DEPOSIT OF TYPES.-The holotype (slide SMLA 12050) and 18 paratypes (15 female, 3 male; slides SMLA 12026, 12042, 12050, $12051,12055,12058-12060,16002,16005)$ are deposited in the W.A.K. Seale Museum, Department of Biology and Health Sciences, McNeese State University, Lake Charles, Louisiana 70609, USA.

DESCRIPTION OF HOLOTYPE.-Measurements in Table 1. Female. Body white or transparent, cuticle sculptured, with 9 dorsal and lateral transverse bands (Fig. 1A), each with reticulated pattern of irregular polygons with diameter 0.7-1.3 m (Fig. 1B). Dorsal gibbosities absent. Eyes not visible in mounted specimen. Two lateral and 6 peribuccal papillae present. Buccal apparatus of the Milnesium type (Fig. 1C). Four peribuccal lamellae around the mouth visible with phase contrast microscopy. Buccal tube cylindrical (posterior: anterior width ratio 95\%). Pharyngeal bulb elongated, pear-shaped, and without placoid or septulum.

Claws of the Milnesium type (Figs. 2A-D). Primary claw branches stout, with well-developed accessory points. Claw base + secondary branches stout, with round basal thickenings. External and posterior secondary claws with 2 points, internal and anterior secondary claws with 3 points (i.e., with prominent basal spurs, claw configuration [2-3]-[3-2]). Thick, transverse cuticular bars on first 3 pairs of legs.

REMARKS.-Morphometric data and summary statistics for the holotype and 14 female paratypes are given in Table 1 . The sculptured bands are sometimes very faint on large 
TABLE 1. Morphometric data and $p t$ values of selected characters of 15 specimens of Milnesium lagniappe sp. n. from Calcasieu Parish, Louisiana, USA. Range refers to the smallest and largest structure found among all measured specimens. Abbreviations: $N=$ number of specimens measured, $\mathrm{SD}=$ standard deviation, n.a. $=$ not applicable, $p t=p t$ index (ratio of the length of a given structure to the length of the buccal tube).

\begin{tabular}{|c|c|c|c|c|c|c|c|c|c|}
\hline \multirow[b]{2}{*}{ Character } & \multirow[b]{2}{*}{$N$} & \multicolumn{2}{|c|}{ Range } & \multicolumn{2}{|c|}{ Mean } & \multicolumn{2}{|c|}{ SD } & \multicolumn{2}{|c|}{ Holotype } \\
\hline & & $\mu \mathrm{m}$ & $p t$ & $\mu \mathrm{m}$ & $p t$ & $\mu \mathrm{m}$ & $p t$ & $\mu \mathrm{m}$ & $p t$ \\
\hline Body length & 15 & $624-781$ & $1938-2567$ & 700 & 2199 & 47 & 204 & 696 & 2096 \\
\hline $\begin{array}{l}\text { Peribuccal papilla } \\
\text { length }\end{array}$ & 12 & $6.8-11.1$ & $22.7-34.7$ & 8.9 & 28.0 & 1.2 & 3.6 & 10.3 & 31.0 \\
\hline $\begin{array}{l}\text { Lateral papilla } \\
\text { length }\end{array}$ & 9 & $4.9-9.7$ & $16.9-30.5$ & 7.2 & 23.2 & 1.7 & 5.4 & 5.6 & 16.9 \\
\hline \multicolumn{10}{|l|}{ Buccal tube } \\
\hline Length & 15 & $28.8-35.0$ & n.a. & 31.9 & n.a. & 1.9 & n.a. & 33.2 & n.a. \\
\hline $\begin{array}{l}\text { Stylet support } \\
\text { insertion point }\end{array}$ & 11 & $20.4-24.3$ & $69.7-73.4$ & 22.6 & 71.8 & 1.3 & 3.2 & 23.3 & 70.2 \\
\hline Anterior width & 12 & $20.7-25.1$ & $68.0-77.5$ & 22.9 & 72.0 & 1.5 & 3.2 & 23.0 & 69.3 \\
\hline Standard width & 12 & $19.4-23.6$ & $63.4-77.9$ & 22.0 & 69.0 & 1.3 & 4.0 & 21.4 & 64.5 \\
\hline Posterior width & 12 & $18.9-23.2$ & $61.8-70.8$ & 21.1 & 66.1 & 1.2 & 2.9 & 21.8 & 65.7 \\
\hline $\begin{array}{l}\text { Standard width: } \\
\text { length ratio }\end{array}$ & 12 & $63 \%-78 \%$ & n.a. & $69 \%$ & n.a. & $4 \%$ & n.a. & $64 \%$ & n.a. \\
\hline $\begin{array}{l}\text { Posterior : anterior } \\
\text { width ratio }\end{array}$ & 12 & $86 \%-99 \%$ & n.a. & $92 \%$ & n.a. & $4 \%$ & n.a. & $95 \%$ & n.a. \\
\hline \multicolumn{10}{|l|}{ Claw 1 lengths } \\
\hline $\begin{array}{l}\text { External primary } \\
\text { branch }\end{array}$ & 14 & $14.9-19.9$ & $47.2-59.7$ & 17.0 & 53.3 & 1.4 & 4.1 & 16.6 & 50.0 \\
\hline $\begin{array}{l}\text { External base }+ \\
\quad \text { secondary branch }\end{array}$ & 14 & $13.4-15.8$ & $41.6-51.0$ & 14.4 & 45.3 & 0.8 & 2.8 & 14.0 & 42.2 \\
\hline $\begin{array}{l}\text { Internal primary } \\
\text { branch }\end{array}$ & 15 & $14.5-17.2$ & $46.3-56.3$ & 16.1 & 50.5 & 0.9 & 2.9 & 16.6 & 50.0 \\
\hline $\begin{array}{l}\text { Internal base }+ \\
\quad \text { secondary branch }\end{array}$ & 15 & $11.9-14.7$ & $35.9-47.1$ & 13.1 & 41.2 & 0.8 & 3.0 & 12.3 & 37.0 \\
\hline Internal spur & 15 & $3.1-6.3$ & $10.3-19.1$ & 4.5 & 14.3 & 0.7 & 2.4 & 4.4 & 13.3 \\
\hline \multicolumn{10}{|l|}{ Claw 2 lengths } \\
\hline $\begin{array}{l}\text { External primary } \\
\text { branch }\end{array}$ & 15 & $17.1-20.4$ & $51.7-63.5$ & 18.4 & 57.9 & 0.8 & 3.5 & 19.1 & 57.5 \\
\hline $\begin{array}{l}\text { External base }+ \\
\quad \text { secondary branch }\end{array}$ & 15 & $13.5-16.1$ & $40.4-50.7$ & 14.5 & 45.7 & 0.6 & 3.2 & 14.1 & 42.5 \\
\hline $\begin{array}{l}\text { Internal primary } \\
\text { branch }\end{array}$ & 15 & $14.9-20.1$ & $48.8-62.1$ & 17.3 & 54.3 & 1.4 & 3.4 & 17.5 & 52.7 \\
\hline $\begin{array}{l}\text { Internal base }+ \\
\quad \text { secondary branch }\end{array}$ & 14 & $12.0-15.7$ & $36.2-47.1$ & 13.3 & 41.8 & 0.9 & 3.1 & 13.3 & 40.1 \\
\hline Internal spur & 14 & $3.0-5.4$ & $9.0-17.6$ & 4.6 & 14.4 & 0.7 & 2.2 & 4.6 & 13.9 \\
\hline \multicolumn{10}{|l|}{ Claw 3 lengths } \\
\hline $\begin{array}{l}\text { External primary } \\
\text { branch }\end{array}$ & 14 & $16.4-19.7$ & $49.7-63.0$ & 17.8 & 56.1 & 1.2 & 3.5 & 18.1 & 54.5 \\
\hline $\begin{array}{l}\text { External base }+ \\
\quad \text { secondary branch }\end{array}$ & 12 & $12.8-16.1$ & $40.5-51.4$ & 14.4 & 45.7 & 0.9 & 3.2 & 14.6 & 44.0 \\
\hline $\begin{array}{l}\text { Internal primary } \\
\text { branch }\end{array}$ & 14 & $16.0-19.3$ & $50.0-60.1$ & 17.5 & 55.2 & 0.9 & 3.1 & 17.7 & 53.3 \\
\hline $\begin{array}{l}\text { Internal base }+ \\
\quad \text { secondary branch }\end{array}$ & 11 & $12.4-14.6$ & $39.1-48.3$ & 13.5 & 42.6 & 0.7 & 2.7 & 13.7 & 41.3 \\
\hline Internal spur & 11 & $3.5-6.1$ & $11.6-17.7$ & 5.0 & 15.7 & 0.8 & 2.2 & 4.5 & 13.6 \\
\hline \multicolumn{10}{|l|}{ Claw 4 lengths } \\
\hline $\begin{array}{l}\text { Anterior primary } \\
\text { branch }\end{array}$ & 14 & $20.1-24.4$ & $62.9-74.0$ & 22.0 & 69.0 & 1.3 & 3.1 & 22.8 & 68.7 \\
\hline $\begin{array}{l}\text { Anterior base }+ \\
\quad \text { secondary branch }\end{array}$ & 15 & $14.2-17.7$ & $42.5-55.9$ & 15.7 & 49.4 & 1.0 & 3.1 & 15.5 & 46.7 \\
\hline Anterior spur & 14 & $4.2-6.5$ & $13.8-22.6$ & 5.2 & 16.3 & 0.6 & 2.4 & 5.5 & 16.6 \\
\hline $\begin{array}{l}\text { Posterior primary } \\
\text { branch }\end{array}$ & 14 & $20.9-25.7$ & $66.1-76.6$ & 22.6 & 70.9 & 1.4 & 3.3 & 22.5 & 67.8 \\
\hline $\begin{array}{l}\text { Posterior base }+ \\
\quad \text { secondary branch }\end{array}$ & 14 & $15.3-17.9$ & $45.8-57.6$ & 16.3 & 51.2 & 0.9 & 3.2 & 15.6 & 47.0 \\
\hline
\end{tabular}




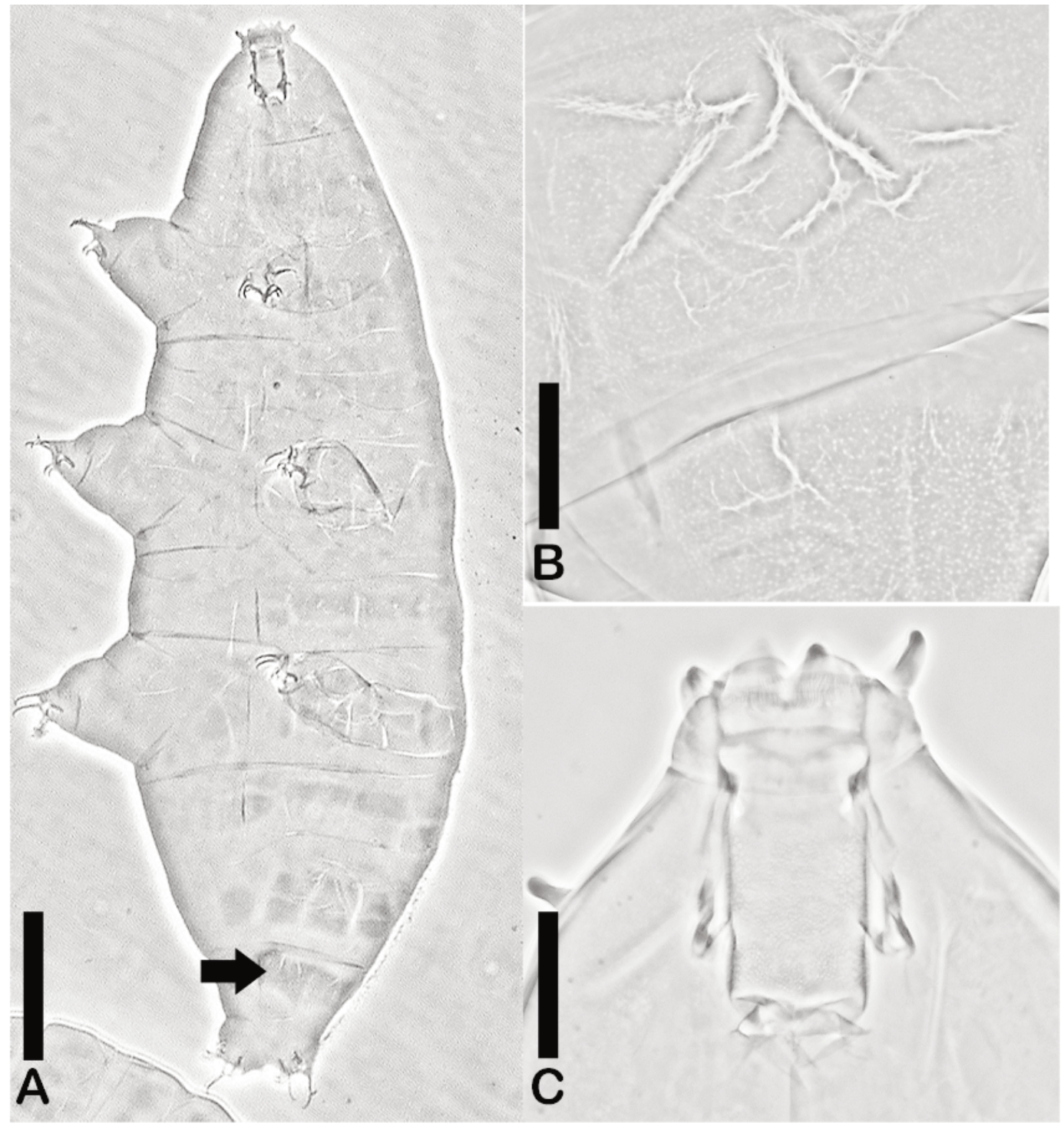

Fig. 1. Milnesium lagniappe sp. n. paratype: A, habitus (arrow indicates a band of sculpture); B, caudal sculptured band in specimen $709 \mu \mathrm{m}$ long; C, buccal apparatus. Scale bars: A, $100 \mu \mathrm{m}$; B-C, $20 \mu \mathrm{m}$.

specimens; they are very evident in smaller specimens (274-383 $\mu \mathrm{m}$; Fig. 3); the size range of individual polygons is the same in both small and large specimens. Two exuvia were found with 13 and 8 eggs with smooth surfaces.

Males have proportionately larger secondary claws in legs 1 and 2 than females. External/anterior claw ranges in 3 males, body length 346-425 $\mu \mathrm{m}$ : claw 1 primary branch 11.5-14.6 um [45.8-61.3], claw 1 base + secondary branch 12.7-13.7 $\mu \mathrm{m}$ [50.6-61.7]; claw
2 primary branch $15.9-16.3 \mu \mathrm{m}$ [61.9-64.9], claw 2 base + secondary branch 10.6-11.7 $\mu \mathrm{m}$ [43.4-47.7], claw 3 primary branch 14.0$16.1 \mu \mathrm{m}$ [61.0-63.1], claw 3 base + secondary branch 11.6-12.4 [49.4-52.3], claw 4 primary branch 14.2-18.1 um [61.4-70.4], claw 4 base + secondary branch 11.7-13.2 $\mu \mathrm{m}$ [45.5- 55.0].

Specimens from Lee County, Florida, identified by Meyer (2008) as Milnesium tardigradum Doyère, 1840, were reexamined and found to be in fact M. lagniappe sp. n. Specimens of 


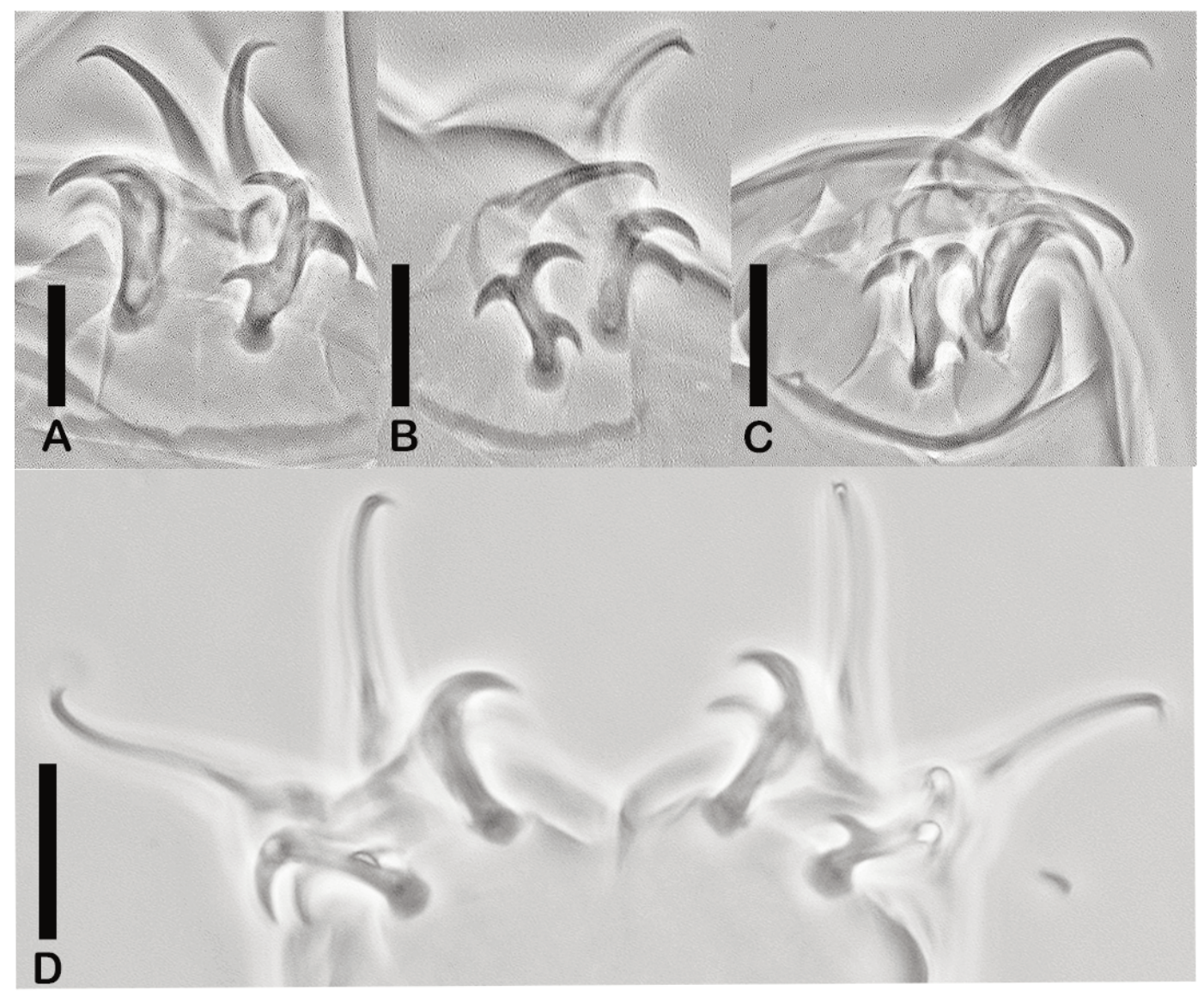

Fig. 2. Milnesium lagniappe sp. n. paratype. Claws: A, leg 1; B, leg 2; C, leg 3; D, leg 4. Scale bars: $10 \mu \mathrm{m}$.

the new species from Florida all had eyes, but the eyes were visible in only one paratype from Louisiana.

In Lake Charles and SHJSP, specimens of Milnesium lagniappe sp. $\mathrm{n}$. were in several instances found in the same samples as an undescribed Milnesium sp. n. with claw configuration [3-3]-[3-3].

Differential Diagnosis.- - Most species of Milnesium have 6 peribuccal lamellae, differentiating them from Milnesium lagniappe sp. n., which has only 4 visible with phase contrast microscopy. Only M. reticulatum, a species from the Seychelles Islands (Pilato et al. 2002), and M. tetralamellatum Pilato and Binda, 1991, from Tanzania and the Seychelles (Pilato and Binda 1991), share this characteristic. The new species has a proportionately wider buccal tube than M. tetralamellatum ( $p t 49.1$ in a 645- $\mu \mathrm{m}$ specimen of M. tetralamellatum and pt 63.4-77.9 in the new species) with a more posterior stylet support insertion point ( $p t$ 62.0-64.4 in M. tetralamellatum, pt 69.7-73.4 in M. lagniappe sp. n.). Moreover, the new species can be distinguished from M. tetralamellatum in having 9 sculptured transverse bands rather than a smooth cuticle.

Both Milnesium lagniappe and $M$. reticulatum have 9 bands wherein the cuticle has a reticular design with irregular polygons. The new species lacks the gibbosities found in $M$. reticulatum. It also reaches a much larger size than $M$. reticulatum (maximum length $405 \mu \mathrm{m}$ in $M$. reticulatum, $760 \mu \mathrm{m}$ in M. lagniappe sp. n.). Milnesium lagniappe sp. n. differs from $M$. reticulatum in having a more posterior stylet support insertion point, albeit with some slight overlap ( $p$ t 68.5-69.8 in M. reticulatum, pt 69.7-73.4 in the new species), a much wider buccal tube ( $p t$ 30.4-37.4 in M. reticulatum, 


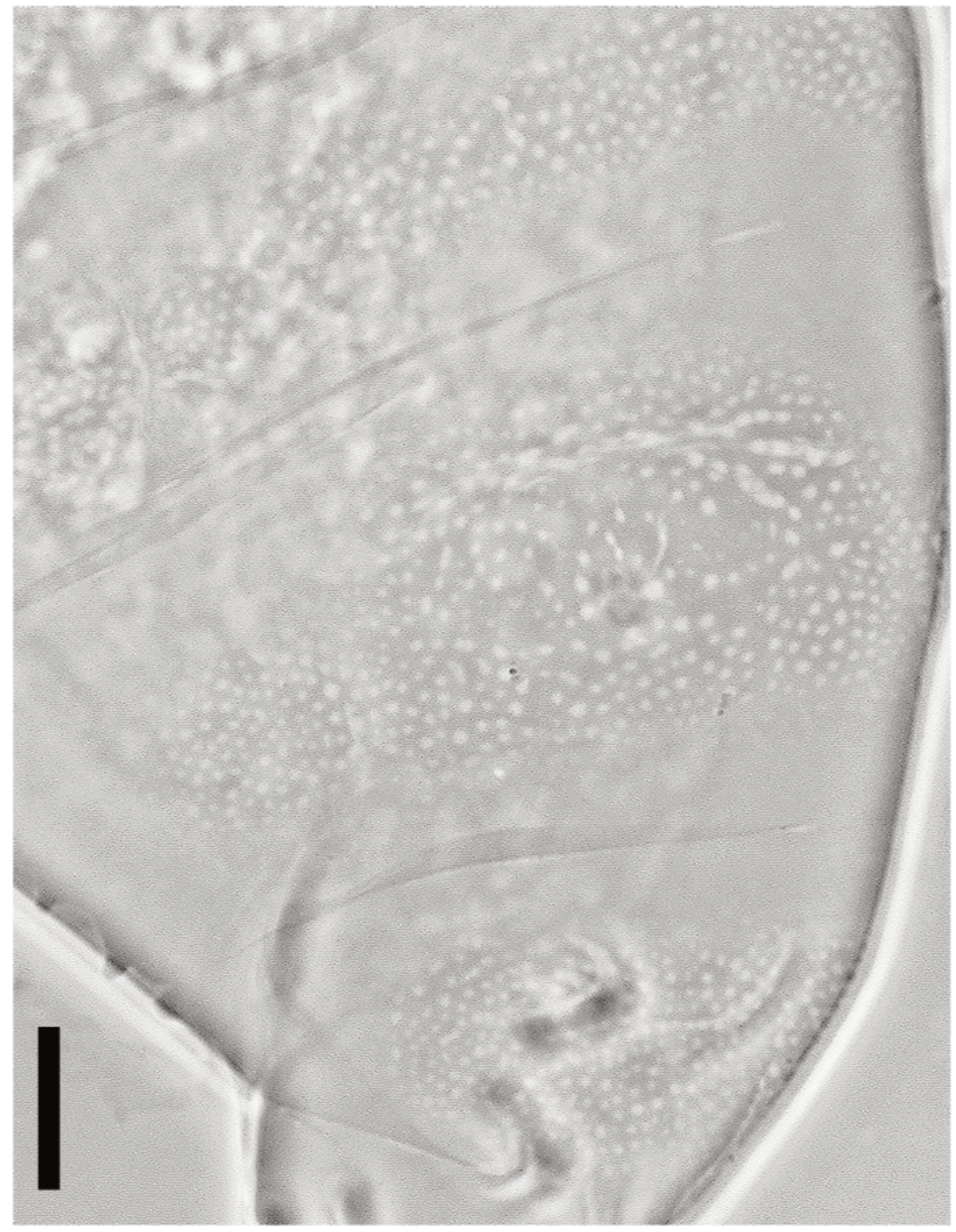

Fig. 3. Milnesium lagniappe sp. n. Caudal sculptured bands in a specimen $312 \mu \mathrm{m}$ long. Scale bar: $10 \mu \mathrm{m}$.

pt 63.4-73.4 in the new species), and proportionally longer claws (e.g., claw 2 external primary branch $p t 33.2-36.6$ in M. reticulatum, pt 51.7-63.5 in M. lagniappe sp. n.).

EтYмOLOGY.-The specific name lagniappe (pronounced lán-yap) is a noun in apposition. In Louisiana French a lagniappe is an "unexpected benefit." The name was chosen because the specimens in Louisiana were collected as part of an urban ecology study.

\section{DISCUSSION}

The addition of M. lagniappe sp. n. to the fauna of Louisiana and Florida raises the number of tardigrade species recorded in those states to 20 and 21, respectively. Michalczyk et al. (2012a, 2012b) divided species of Milnesium into the tardigradum group, with smooth cuticles, and the granulatum group, with sculptured (reticulated) cuticles. The presence of dorsal and lateral bands of reticulation on M. lagniappe sp. n. clearly places it in the granulatum group.

\section{ACKNOWLEDGMENTS}

We thank Łukasz Michalczyk for invaluable advice on measuring Milnesium buccal tubes. Carrie Samletzka collected many of the 
samples in Lake Charles. Giovanni Pilato kindly loaned 2 specimens of Milnesium reticulatum for comparative purposes.

\section{Literature Cited}

Christenberry, D., and W.H. Mason. 1979. Redescription of Echiniscus virginicus with notes on life history, range, and geographic variation. Journal of the Alabama Academy of Science 50:47-61.

Grigarick, A.A., R.O. Schuster, and D.R. Nelson. 1983. Heterotardigrada of Venezuela (Tardigrada). PanPacific Entomologist 59:64-77.

Hinton, J.G., And H.A. Meyer. 2007. Distribution of limnoterrestrial Tardigrada in Georgia and the Gulf Coast states of the United States of America with ecological remarks. Journal of Limnology 66 (Supplement 1):72-76.

Hinton, J.G., H.A. Meyer, and A.W. Sweeney. 2010. Seasonal and spatial variability in the diversity and abundance of tardigrades in leaf litter from Louisiana and Florida. Southwestern Naturalist 55: $539-543$.

Meyer, H.A. 2001. Tardigrades of Louisiana and Arkansas, United States of America. Zoologischer Anzeiger 540:471-474.

.2006. Interspecific association and substrate specificity in tardigrades from Florida, southeastern United States. Hydrobiologia 588:129-132.

2008. Distribution of tardigrades in Florida. Southeastern Naturalist 71:91-100.

. 2009. Tardigrades of the Florida Keys. Florida Scientist 71:141-146.
Meyer, H.A., And M.N. Domingue. 2011. Minibiotus acadianus (Eutardigrada: Macrobiotidae), a new species of Tardigrada from southern Louisiana, U.S.A. Western North American Naturalist 71:38-43.

Meyer, H.A., and J.G. Hinton. 2007. Limno-terrestrial Tardigrada of the Nearctic Realm. Journal of Limnology 66(Supplement 1):97-103.

Michalczyк, Ł., W. WeŁnicz, M. Frohme, and Ł. KaCZMAREK. 2012a. Corrigenda of Zootaxa, 3153: 1-20 Redescriptions of three Milnesium (Doyère, 1840) taxa (Tardigrada: Eutardigrada: Milnesiidae), including the nominal species for the genus. Zootaxa 3393: $66-68$.

. 2012b. Redescriptions of three Milnesium (Doyère, 1840) taxa (Tardigrada: Eutardigrada: Milnesiidae), including the nominal species for the genus. Zootaxa 3154:1-20.

Pilato, G. 1981. Analisi di nuovi caratterri nello studio degli Eutardigrada. Animalia 8:51-57.

Pilato, G., AND M.G. Binda. 1991. Milnesium tetralamellatum, new species of Milnesiidae from Africa (Eutardigrada). Tropical Zoology 4:103-106.

Pilato, G., M.G. Binda, and O. Lisi. 2002. Notes on tardigrades of the Seychelles with the description of two new species. Bollettino dell'Accademia Gioenia di Scienze Naturali di Catania (Série 4):503-517.

Tumanov, D.V. 2006. Five new species of the genus Milnesium (Tardigrada, Eutardigrada, Milnesiidae). Zootaxa 1122:1-23.

Received 18 December 2012 Accepted 29 May 2013 